\title{
THE CONCEPT OF BUILDER AND ITS LIABILITY FOR THE QUALITY OF THE CONSTRUCTION WORKS IN LITHUANIAN CONSTRUCTION LAW
}

\author{
Renata Cibulskiené ${ }^{1}$, Sigitas Mitkus ${ }^{2}$ \\ Department of Law, Vilnius Gediminas Technical University, Sauletekio al. 11, 10223 Vilnius, Lithuania \\ E-mails: ${ }^{1}$ renata.cibulskiene@vgtu.lt; ${ }^{2}$ sigitas.mitkus@vgtu.lt (corresponding author)
}

\begin{abstract}
A construction process, from the issue of a document allowing construction to signing a transfer- acceptance deed, involves a number of entities for which the law provides for different rights and duties. One of such entities is a builder (customer). The article discusses issues related with the establishment of the builder's duties during the construction process and application of liability for failure to perform them or improper performance thereof. The concept of the builder (customer) is disclosed, and the builder's civil liability for incompliance of construction works with the laws or provisions of the works contract, as well as late performance of construction works are analysed. It is analysed how to identify correctly a builder as one of the main entities of construction and to separate him from other participants of the construction process, such as head of construction or construction technical supervisor. The builder's duties are analysed which improper performance has an effect on the quality of works carried out by the contractor, also issues raised in the Lithuanian case-law are discussed.
\end{abstract}

Keywords: civil liability, construction, concept of builder (customer), construction process, builder's duties, quality of works.

JEL Classification: K12; K39; L74.

\section{Introduction}

A construction process is activity regulated by legal acts the aim whereof is to build (assemble, construct) a new, to reconstruct, repair or to demolish an existing construction works. This process, from the issue of a construction permit to signing a deed of acceptance, involves a number of participants who are prescribed different rights, duties and liability by the law.

One of such participants is a builder (customer). In the Law on Construction of the Republic of Lithuania, nearly everywhere the term "builder" ("customer") is used, except for Article 3, where the term "builder" is used. Meanwhile in the Civil Code of the Republic of Lithuania (LRS 2000), when talking about construction works, the term "customer" is used. The use of different terms causes difficulties in ascertaining as who is the builder, what rights and duties are prescribed for by him by the laws, as the terms of the customer and the builder are not identical (Saukalienè 2010).

The builder is always interested that a construction project is implemented successfully, i.e. was finished on time, not exceeded the estimated budget, conformed to technical specifications and the builder's needs (Karna 2004). In order a construction project proceeded successfully, the builder must take an active participation in it and establish the conditions for a successful process. Both, the Law on Construction of the Republic of Lithuania and the Civil Code of the Republic of Lithuania (LRS 1996, 2000), prescribe for the builder in the construction process not only rights, but also duties, therefore, in the event of failure to perform them or improper performance thereof, the builder may incur liability for improperly performed construction works.

Rights and duties of the builder are described in detail in contracts entered into during the construction process. Most often these are works contracts between the builder and the contractor, however also a construction management contract may be concluded between the builder and the construction manager - a person who manages construction of a construction works. The builder's rights and duties associated with implementation of a construction project in a proper and timely manner have been analysed in scientific literature rather rarely. The builder's liability for defects of construction products and construction defects have been analysed (Mitkus 2004; Saukalienè 2010; Bryson et al. 2013; Mitkus, S., Mitkus, T. 2014.). The builder's liability during construction by complex designing-construction way was analysed by P. Thomas Gard (Gard 2009); the builder's liability issues for defects of a construction works has been 
discussed in the Australian case-law by C. Kerin and J. Qian (Kerin, Qian 2014), the builder's influence on the end result of the construction process was analysed by A. Vennström and P. E. Eriksson (Vennström, Eriksson 2010), B. Xia and A. P. C. Chan (Xia, Chan 2010). Liability of construction participants for construction defects in the English case-law has been discussed by J. Glover (Glover 2008). The relationship between the builder and the contractor and their effect on project performance have been discussed in works of $\mathrm{Za}-$ ghloul, Hartman (2003), Meng (2012), Ceric (2014), Suprapto et al. (2015a, 2015b).

The goal of this article - to discuss the builder's duties and liability associated with proper implementation of construction project, and to analyse any arising issues.

Applied methods: comparative analysis, systemic, linguistic.

\section{Identification of the builder and distinguishing thereof from other participants of construction}

The Law on Construction of the Republic of Lithuania (LRS 1996) provides for different construction methods - contracts for work, construction using own resources, mixed method, management of a construction works, etc. Depending on the chosen construction methods, different participants participate in the construction process: builder (customer), investigator, designer of a construction works, technical supervisor of construction of a construction works, supplier, manager of construction of a construction work, manager of the design documentation of construction works.

In a large construction project, a number of parties are involved, and a network of contractual relationships is thus established. The construction sector is a prime example of a project example of a project-based industry, in which new product development involves not only non-routine production processes, but also complex working relationships and interrelation (Buvik, Rolfsen 2015). In the traditional building project, a contract of construction works is concluded between the builder (customer) and the contractor. The fundamental risk allocation and delivery method must be stipulated in the main contract (Klee 2015). Further, the main contractor concludes separate contacts with co-contractors and suppliers. If construction is carried out by way of management of a construction works, the construction and works associated with it in other fields of construction technical activity are organized by the manager of construction of a construction work on the basis of agreement between the principal - builder (customer) and the agent - manager of construction of a construction works (Young-Jun 2013).

In Lithuania, no separate types of contracts entered into during the construction process have been clearly distinguished. In foreign countries, however, e.g. in the USA and UK, specific systems of construction contracts have been distinguished under which the builder's responsibility is different (Oyegoke 2001). The builder (customer) is the main entity of construction, and without this entity, it would not be possible to proceed with construction. The research showed that the builders play the most important role in determining project success (Wang, Huang 2006). Article 2 of the Law on Construction of the Republic of Lithuania is described as a natural or legal person of Lithuania or a foreign state who invests funds into construction and performs at the same time functions of a builder (customer) (or transfers such functions to any other natural or legal person).

The Law on Construction of the Republic of Lithuania (LRS 1996) does not prescribe any restrictions on natural person to be a builder (there is no restriction on age, citizenship, residential place or any other restrictions) or any other restrictions on a legal entity for being a builder (no requirements for the type, place of registration, etc.). The builder may be any natural or legal entity if he meets two distinctive features of the builder (customer) as a construction entity: invests funds into construction and performs (assigns to another person) the functions of the customer.

Seeking to implement the right to be a builder, the person must satisfy particular conditions laid down in Article 3(2) of the Law on Construction of the Republic of Lithuania (LRS 1996): the builder must own a plot of land or hold and use it on other grounds established by the laws (not applied in the cases prescribed by the Ministry of Environment, when plots of land have not been formed (when renewing (modernizing buildings, carrying out major repairs or current repairs of a construction works, etc.); to have a document authorizing construction (when it is compulsory); to hold a construction works by the right of ownership or to hold and use it under the grounds laid down in the laws (in the cases of reconstruction, repair and demolishment of a construction works). The indicated requirements are not applied if construction works are demolished at the order of courts,

Although the features of the builder (customer) have not been clearly defined in the Law on 
Construction of the Republic of Lithuania, there have been cases in practice when it is difficult to establish which entity is actually the builder (customer). The clearest situation is in the case when the builder concludes a contract of construction works; then he has the rights, duties and liability provided for in the Civil Code of the Republic of Lithuania according to general and special conditions (construction contracts, use contract). The builder, however, does not necessary personally performs functions of the customer - the law establishes a possibility to assign their performance to the manager of construction of a construction works who acts on behalf of the builder (customer) as his agent. The scope of works assigned to the manager of construction works and rights and duties of the manager of construction of a construction works are determined in the mandate agreement. By its nature, the mandate agreement may be an agreement on representation, when one party (an agent) undertakes to perform particular legal actions with third persons on behalf of the other party (principal) (Campbell 2009; Mitkus, Jurkevičius 2014; Saukalienė 2011). Twofold relationships arise on the basis of representation - between the agent and the person being represented: internal - between the agent and the principal; and external - between the agent and third persons with whom the agent concludes transactions or performs other legal actions on behalf and in the interests of the person he represents. The agent acting under the mandate agreement acts not in his own interests, but in the interests of the principle, whereas legal consequences of his actions are borne by the principal. This leads to the conclusion that when carrying out construction by the way of construction management, the builder's liability is not shifted to the manager of construction. The Supreme Court of Lithuania noted that liability of the builder for legal consequences of actions by the manager of a construction works who acted as an agent of the builder in relationships with third persons is borne by the principal, i.e. the builder (Supreme Court of Lithuania 2012).

Another situation, where the problem of the builder's identification is encountered, is when construction works are carried out in a multiapartment residential building and it is not known for sure who is an owner: the association or a separate co-owner of a separate flat. A dispute may arise between a co-owner, the association and coowners regarding the scope and necessity of works performed on the basis of construction works contract between the association and the third person, or payment for them, therefore it is necessary to determine who the builder is and who incurs the duty to settle accounts with the contractor. An apartment owners association is one of the forms of managing an object in common partial ownership. According to the Law on Associations of Owners of Multi-Apartment Residential Buildings of the Republic of Lithuania, an association of a multi-apartment residential building, is a non-profit legal entity that implements general rights, duties and interests of owners of premises in the building, associated with management, use, maintenance and operation of common use objects in the house and of the plot of land assigned to the house under the procedure laid down in the laws. Although the association is a legal person of limited civil liability, it, as a subject of civil liability, however, has peculiarities determined by the fact that an owner of the common use objects in the house is not the association, but the owners of flats who have the right to dispose of these objects. If a co-owner concluded a contract for the performance of works associated with common-use premises, equipment and other property in the multi-apartment residential building under the right of common partial ownership directly with the contractor, in case of a dispute the parties shall be subject to the standards regulating not internal (Articles 4.82-4.85 of the Civil Code of the Republic of Lithuania), but external - contract - relationships $\left(36^{\text {th }}\right.$ chapter of the sixth book of the Civil Code of the Republic of Lithuania) (Supreme Court of Lithuania 2011), and not the association, but an owner of each separate flat shall be recognized as the contractor. In another case, however, when solving whether one of the co-owners has the right to organize repair works of common-use objects, the Supreme Court of Lithuania stated that as to the repairs of common-use objects, a decision is taken by co-owners (except for the cases indicated in legal acts, when this may be done by the administrator), whereas a decision of co-owners is implemented through the administrator, this way implying that only the association may be a builder (Supreme Court of Lithuania 2015).

According to the Law on Construction of the Republic of Lithuania (LRS 1996), one of the conditions seeking to implement the right to be a builder is to hold and (or) use a plot of land under the ownership right or other grounds, however the law does not discuss the situation when a construction works is built not on the plot of land, but on a water body. The law does not deal with the right of a person who is not an owner (holder) of a water body, to be a builder. Thus, may a person who owns a plot of land bordering with the adjacent 
water body belonging to another person be a builder and build a non-complicated construction works in the water body, e.g. a foot-bridge? Interpreting the Law on Construction of the Republic of Lithuania linguistically, a person who is not an owner of the water body may not be a builder, as he does not satisfy the condition laid down in Article 3(2)(1) of the Law on Construction. According to Article 7 of the Law on Water of the Republic of Lithuania (LRS 1997), a basis to use a water body is the ownership right, lease or other agreement, also any other rights granted by this law or legal acts. If a person does not have an ownership right to the water body, or does not hold it under contractual basis, this does not mean that he may not use it according to the law as an owner of the land plot bordering with the adjacent water body. According to the Law on Construction, in the water body, the builder's right may be implemented by an owner of this water body, whereas the owner of the land plot bordering with the adjacent water body may be recognized as the builder by decision of a court. Such a conclusion is also confirmed by the case law. When hearing a dispute, the Supreme Court of Lithuania has noted that a person who became an owner of the water body may not restrict the right of owner of the adjacent plot of land to use the water body without a legal basis. The owner of the adjacent land plot relates construction of noncomplicated construction works (pontoon bridges) with the implementation of the right to use a water body provided for in the law, therefore a person's refusal to give consent for building foot-bridges under the grounds of an absolute ownership right and without providing other arguments of such refusal restrict the right of owner of the adjacent land plot to use the water body. The Supreme Court of Lithuania stated that an owner of the land plot bordering with the adjacent water body may be a builder in the sense of Article 3(2)(1) of the Law on Construction (Supreme Court of Lithuania 2012).

In practice, some confusion regarding the builder arises, when construction works are carried out in the premises used under the loan-for-use agreement. A works contract is an agreement by which the contractor undertakes to carry out particular works at his risk according to the customer's assignment and to transfer the results of this work to the customer, whereas the customer undertakes to accept the accomplished work and to pay for it. In the event of a dispute regarding the works contract and payment for accomplished works, it is necessary to justify not only the existence of contractual legal relationships, but also to prove who the participant of legal relationships of the works contract is - customer of the contract work. The loan recipient shall be obliged to maintain and preserve the thing transferred to him under the contract, likewise to perform current and capital repair, and to bear all expenses for the maintenance thereof unless otherwise provided for by the contract (Article 6.636 of the Civil Code of the Republic of Lithuania). The law provides for a duty of the loan recipient to perform current and capital repair; however, the parties may lay down in the contract that such duty is assumed by the lender. Thus, if premises are managed under the grounds of a loan-for-use agreement (uncompensated use of the thing), the customer may be both, the lender who is an owner of the thing or a person authorized by the law or by the owner of the thing, as well as the loan recipient. Further, it is important to assess the conditions laid down in the loan-for-use agreement related with the performance of construction works, nature of ongoing contract works and the legal status of premises. Assessing a situation under dispute, when plumbing works (installation of a heating system) had been carried out in the premises used under the loan-for-use agreement, the Supreme Court of Lithuania noted that rights and duties of the parties in maintaining and repairing the premises were discussed in the loanfor-use contract concluded by the parties, including the duty of the lender to perform reconstruction and repair works in the premises discussed in the agreement. Therefore it is necessary to assess whether the accomplished works consisting of the installation of a heating system in the premises is a significant improvement of the premises belonging to the lender, whether the accomplished works are considered to be reconstruction (repair works) of the premises by their nature. The cassation court also noted that it was necessary to assess the lender's letter regarding the payment of works and other evidence associated with it (Supreme Court of Lithuania 2010). It is noteworthy that after repeat hearing of the case Kaunas Regional court admitted that actual relationships of the works contract were established between the contractor and the lender, as, after the accomplishment of works, the premises belonging to the lender were improved, besides, the lender undertook to pay for the works (Supreme Court of Lithuania 2011).

\section{Contractual civil liability of the builder for the quality of works}

The contractor undertakes under the construction works contract to build a construction works or to 
perform other construction works within the timelimit fixed in the contract according to the customer's assignment, therefore the contractor is liable for the customers for deviations from the requirements of the technical construction regulations and also for the failure to achieve the indicators of the objects of construction specified in these documents or the contract (Article 6.695 (1) of the Civil Code of the Republic of Lithuania). Although it is a duty of the contractor to perform construction and other works specified in the works contract, under particular circumstances, however, the customer also incurs civil liability for improperly performed construction works.

Civil liability arises from non-performance or improper performance of a duty established by a contract or from violation of the general duty to behave with care (Article 6.246 (1), 6.256 (1) of the Civil Code of the Republic of Lithuania). According to the general rule, a legally concluded and valid contract has the power of the law for the parties. The contract binds the parties to fulfil not only what is directly provided for therein, but also all that what is determined by the subject-matter of the contract orf the laws. (Article 6.189 (1) of the Civil Code of the Republic of Lithuania), therefore contractual civil liability may arise not only for violating the contract, but also for failure to perform the duties laid down in the laws. The laws and legal acts implementing them lay down particular behavioural standards, some - dispositionally, others imperatively, and they must be complied with not only by the contractor, but also by the customer in the contract process. If the customer does not act prudently, carefully, does not take sufficient measures to implement provisions of the contract and legal standards regulating his duties, these are illegal actions (omission) of the defendant, i.e. one of the conditions of applying civil liability. Contractual civil liability is material obligation in which one party is entitled to claim indemnification for damage or contractual penalty, whereas the other party must reimburse for losses resulting from failure to perform the contract or improper performance thereof. The Civil Code foresees the cases when the contractor incurs liability for improperly accomplished construction works, if the customer fails to perform or improperly performs the duties prescribed in the Civil Code.

First of all, the customer must assume liability for minor deviations from the technical construction regulations made with the consent of the customer if he proves that these deviations have not influenced the quality of a construction object and will not bring about negative consequences (Article 6.695 (3) of the Civil Code of the Republic of Lithuania) (Keane et al. 2010). The customer or persons hired by him shall be liable for the defects discovered within the guarantee period unless it is proved that the defects occurred as a consequence of the normal wear and tear of the objects or parts thereof, its inappropriate use, or improper repair made by the customer or third persons engaged by him, or any other faulty actions of the customer or third persons engaged by him (Article 6.697 (3) of the Civil Code of the Republic of Lithuania). Also, the customer must take into consideration a reasonable and timely warning about circumstances threatening the fitness of the ongoing works and replace unfit or inferior quality materials, other property or documents, or to change his instructions concerning the methods of the fulfilment of work, or to eliminate other circumstances which threaten the fitness or stability of the work to be fulfilled (Article 6.659(3) of the Civil Code of the Republic of Lithuania). Besides, Article 12(1) of the Law on Construction lays down essential duties of the builder (customer). The builder (customer) must: submit to a designer mandatory documents related to the preparation of a design documentation; organise expert examination of a design documentation of a construction works; organise and carry out technical supervision of the construction; organise supervision of the implementation of a design documentation of a construction works; organise in the prescribed manner the acceptance of the completed construction works as fit for use. Upon failure to perform or improper performance of these duties, also other duties provided for in the contract for the customer, the customer incurs civil liability, i.e. the customer may have to reimburse for loss sustained by the contractor, or the court may cut down the amount of losses claimed by the customer from the contractor due to defects of construction works.

In the event construction works are improperly fulfilled, it is necessary to determine in each specific case the causes giving rise to the defects and to relate them with actions not fulfilled or improperly fulfilled by the persons liable for the defects in order to resolve the sharing of liability between participants of the construction process (Jingmond, Agren 2015). The customer's willingness to conclude a construction works contract is determined by his demand for a specific work or the results thereof, meanwhile the contractor usually acts in the construction works contract as a professional, engaged in his business, therefore the 
law provides a greater liability for the contractor for proper results of the construction works contract than that for the customer.

The case-law in solving disputes between the customer and the contractor is not unequivocal. The courts differently assess the customer's duty to carry out technical supervision. The Civil Code of the Republic of Lithuania lays down that the customer shall have the right to effectuate control and supervision over the course and the quality of construction work being fulfilled, whereas the contractor who improperly fulfilled the contract, he shall have no right to rely on the fact that the customer failed to effectuate control and supervision of the construction work, except in the cases where the duty of the customer to perform such control and supervision is established by the law or contract (Article 6.689 of the Civil Code of the Republic of Lithuania). Meanwhile the Law on Construction of the Republic of Lithuania (LRS 1996) lays down that the builder (customer) must organize and carry out technical supervision of a construction works. It may be concluded that the contractor may always rely on such a circumstance, as the law prescribes such a duty for the customer, and it is not important that this duty is not provided for in the construction works contract, as rights and obligations of parties to the construction works contract may be regulated by the construction works contract to the extent they are not imperatively determined by the laws. The Supreme Court of Lithuania has stated that unless the law or contract provides for otherwise for the customer, control and supervision over construction works is the right, and not a duty. The contractor who has improperly fulfilled the contract, does not have the right to rely on the fact that the customer did not effectuate control and supervision of construction works, except for the case when the duty of such control and supervision is imposed on the customer by the law or contract (Supreme Court of Lithuania 2009, 2015). In another case, however, the court dismissed the customer's claim for indemnification of damages and stated that the plaintiff was obligated to effectuate technical supervision of a construction works, yet failed to discharge it; he could and had to demand the defendant to fulfil construction works in a proper and quality way, however did not exercise this right; therefore, it could be concluded that the plaintiff did not prevent the emergence of construction defects. Such behaviour does not comply with a prudent and careful behaviour (Kaunas Regional Court 2013). When hearing the dispute the Court of Appeal of Lithuania ruled out that since the customer improperly performed the duties laid down in the Law on Construction of the Republic of Lithuania (LRS 1996), including technical supervision, he assumed liability for defects of construction works in equal shares -50 percent each, what served as a basis to apportion the duty of covering the costs on a pro rata basis (Court of Appeal of Lithuania 2014). The Supreme Court of Lithuania approved such case-law by stating that failure to perform the duty to effectuate technical supervision over works prescribed for the customer in the law and contract had significance for the accrual of amounts claimed to be reimbursed by the customer, and therefore, after assessing the significance of failure to fulfil this duty for the accrual of the customer's losses, the level of amounts claimed to be reimbursed was cut down by 10 percent (Supreme Court of Lithuania 2015).

Articles 6.696 and 6.697 of the Civil Code of the Republic of Lithuania provide for the allocation of liability for defects of a construction works between the customer, technical supervisor and the contractor. The Supreme Court of Lithuania has expressed an opinion that crucial significance when deciding who is liable for the executed works of inferior quality, is given to the establishment of causal link giving rise to defects and actions of participants in the legal relationships of construction works contract (customer, contractor, technical supervisor) (Supreme Court of Lithuania 2014a, 2014b).

Irrespective of the fact that according to Article 16(1) of the Law on Construction of the Republic of Lithuania (LRS 1996) the builder (customer) must organize technical supervision of construction of a construction works by appointing or hiring a technical supervisor, the customer and construction technical supervisor are separate participants of construction who have different rights and duties, therefore the grounds of their liability for improperly fulfilled duties are different. A technical supervisor of construction of a construction works may be a legal entity with whom a contract on technical supervision is concluded; a structural unit of the builder (customer) or an employee of the builder (customer) authorized to effectuate technical supervision; a natural person with whom the builder (customer) concludes a civil or labour contract. If the builder's (contractor's) structural unit or employee carries out technical supervision, upon improper performance of such duties, the customer may incur liability on different grounds: as a party to the construction works contract that violated the duties, or as a person hiring an employee (construction technical supervisor) who must indemnify for damage 
caused by the fault of his employees in the performance of their service (official) duties (Article 6.264 of the Civil Code of the Republic of Lithuania). Such a conclusion is confirmed by the case law. In the cases when the customer deviates from the design documentation at his initiative, whereas technical supervision and control is effectuated by his representative, the contractor's liability for defects may be reduced by reducing the award of damage to be compensated for the customer for the defects of a construction works (Supreme Court of Lithuania 2006). Besides, the Supreme Court of Lithuania has stated in a number of cases that if a construction technical supervisor appointed by the customer's employee improperly performs his duties, the customer may incur liability as the person hiring the employee (Supreme Court of Lithuania 2014a, 2014b).

\section{Conclusions}

1. Seeking to identify the builder, consideration should be made not only to the features of the builder and conditions set out in the Law on Construction of the Republic of Lithuania (LRS 1996), but also to the provisions of the Civil Code of the Republic of Lithuania or other laws and legal acts. The scope of works assigned to the manager of construction of a construction works, as well as rights and duties of the manager of construction of a construction works are determined in the mandate agreement.

While building by the way of construction management, the builder's liability is not shifted on the construction manager. In relationships with third persons, the manager of construction of a construction works acts as the builder's agent, and legal consequences of the actions are borne by the principle, i.e. the builder.

2. An association of owners of multi-apartment residential buildings is a person of limited civil liability. It, however, as an entity of civil liability, has some peculiarities determined by the fact that the owner of common use objects of the house is not the association, but owners of flat having the right to dispose of these objects. When solving the issue who may be the builder when performing construction works in common use objects - the association or a separate co-owner of the property - an owner of a separate flat, it is necessary to evaluate a specific situation and to ascertain the entities among which the relationships of construction works contract get established.

3. According to the Law on Construction, one of essential conditions seeking to implement the right to be a builder, is to hold and (or) to use a plot of land by the right of ownership or under other grounds. For building in the water body, the builder's right under the Law on Construction may be only implemented by the owner of this water body, whereas the owner of the plot of land bordering with this water body may be recognized as the builder by a court decision, since the person, upon becoming an owner of the water body, may not restrict the right of owner of the adjacent plot of land to use the water body without a legal ground.

4. While carrying out construction works inside premises that are managed under the loan-foruse agreement, the lender may be recognized as the builder, if the loan-for-use agreement provides for his duty to carry out current and major repairs, whereas the construction works fulfilled meet the concept of current or capital repairs, whereas the lender has undertook to pay for the repair works.

5. One of essential duties of the customer is to effectuate technical supervision of construction of a construction works, that is assessed in the caselaw not unequivocally. The most recent case-law stresses the duty for the customer to properly perform the duty prescribed in the law - to effectuate technical supervision over construction, whereas upon failure to perform this duty, reduces the amount of loss to be compensated for the customer.

6. The Customer and construction technical supervisor are separate participants of construction who have different rights and duties, therefore the grounds for their liability for failure to perform or improper performance of the duties are different. When technical supervision of construction is carried out by the builder's (customer's) a structural unit or employee, if he improperly performs his duties, the customer may incur liability either as a party to the construction works contract which violated the duties, or as a person hiring the employee (technical supervisor of construction) who must indemnify for the damage caused by the fault of his employees in the performance of their service (official) duties.

\section{References}

Bryson, D. K.; Hausler, K. F.; Jackson, G. W. 2013. Liability issues in construction defect cases [online]. Lewis \& Roberts, PLLC, Raleigh [cited 20 January 2016]. Available from Internet: http://www.lewis-roberts.com/Liability-Issues-inConstruction-Defect-Cases-00261043.pdf

Buvik, M. P.; Rolfsen, M. 2015. Prior ties and trust development in project teams - a case study from the 
construction industry, International Journal of Project Management 33: 1484-1494.

http://dx.doi.org/10.1016/j.ijproman.2015.06.002

Campbell, D. (Ed.) 2009. International agency and distribution law, Vol. 2. Salzburg: Center for International Legal Studies.

Ceric, A. 2014. Strategies for minimizing information asymmetries in construction projects: project managers' perceptions, Journal of Business Economics and Management 15(3): 424-440. http://dx.doi.org/10.3846/16111699.2012.720601

Court of Appeal of Lithuania. 2014. UAB „Gesika“ v. $B U A B$,Narvis “, $S$. N. Court of Appeal of Lithuania, Case No. 2A-1320/2014.

Gard, P. T. 2009. Fast and innovative delivery of high performance building: design-build delivers with less owner liability, Strategic Planning for Energy and the Environment 3(4): 7-22.

Glover, J. 2008. Liability for defects in construction contracts-who pays and how much? Fenwick Elliot.

Jingmond, M.; Agren, R. 2015. Unravelling causes of defects in construction, Construction Innovation 15(2): 198-218.

http://dx.doi.org/10.1108/CI-04-2014-0025

Kaunas Regional Court. 2013. UAB „Kauno audiniu projektas“ v. UAB „Betonika“, UAB „,Mitnija“, UAB DK „PZU Lietuva“. Kaunas Regional Court, Case No. 2-466-259/2013.

Karna, S. 2004. Analysing customer satisfaction and quality in construction - the case of public and private customers, Nordic Journal of Surveying and Real Estate Research, Special Series 2: 6780.

Keane, P.; Sertyesilisik, B.; Ross, A. 2010. Variations and change orders on construction projects, Journal of Legal Affairs and Dispute Resolution in Engineering and Construction 2(2): 89-96.

http://dx.doi.org/10.1061/(ASCE)LA.19434170.0000016

Kerin, C.; Qian, J. 2014. Building and construction: the high court decides: when does a builder owe a subsequent owner a duty of care?, LSJ: Law Society of NSW Journal 1(6): 70-71.

Klee, L. 2015. International construction contract law. John Wiley\&Sons. http://dx.doi.org/10.1002/9781118717868

Law on Associations of Owners of Multi-Apartment Residential Buildings. 1995. Valstybès žinios, No. 20-449.

Lietuvos Respublikos Seimas (LRS). 1996. Law on Construction, Valstybès žinios No. 32-788.

Lietuvos Respublikos Seimas (LRS). 1997. Law on Water, Valstybès žinios No. 104-2615.

Lietuvos Respublikos Seimas (LRS). 2000. Civil Code of the Republic of Lithuania, Valstybès žinios No. 74-2262.
Meng, X. 2012. The effect of relationship management on project performance in construction, International Journal of Project Management 30(2): 188198.

http://dx.doi.org/10.1016/j.ijproman.2011.04.002

Mitkus, S. 2004. Statybos dalyvių rizika ir atsakomybė už statybos produktų defektus [The risks and liability of participants of a construction process for defects of building products], Ūkio technologinis ir ekonominis vystymas 10(3): 109-115.

Mitkus, S.; Jurkevičius, V. 2014. Agency law in business relationships: the main characteristics from a comparative perspective, in $8^{\text {th }}$ International Scientific Conference Business and Management 2014, 15-16 May 2014, Vilnius, Lithuania.

Mitkus, S.; Mitkus, T. 2014. Causes of conflicts in a construction industry: a communicational approach, Procedia - Social and Behavioral Sciences 110: 777-786.

http://dx.doi.org/10.1016/j.sbspro.2013.12.922

Oyegoke, A. S. 2001. Uk and US construction management contracting procedures and practices: a comparative study, Engineering, Construction and Architectual Management 5/6: 403-417.

http://dx.doi.org/10.1046/j.1365-232X.2001. 00222.x

Saukalienè, K. 2010. Statybos defektai ir užsakovo atsakomybès už juos problemos [Construction defects and problems of owner liability], Socialiniu mokslu studijos / Social Sciences Studies 2(6): 243-257.

Saukalienè, K. 2011. Statybos valdytojas: samprata ir sutartinès atsakomybès ypatumai [Construction manager: the concept and peculiarities of contractual responsibility], Socialiniu mokslu studijos / Societal Studies 3(3): 1111-1128.

Suprapto, M.; Bakker, H. L. M.; Mooi, H. G. 2015a. Relational factors in owner-contractor collaboration: The mediating role of teamworking, International Journal of Project Management 33(6): 1347-1363.

http://dx.doi.org/10.1016/j.ijproman.2015.03.015

Suprapto, M.; Bakker, H. L. M.; Mooi, H. G.;Moree,W. 2015b. Sorting out the essence of ownercontractor collaboration in capital project delivery, International Journal of Project Management 33(3): 664-683.

http://dx.doi.org/10.1016/j.ijproman.2014.05.001

Supreme Court of Lithuania. 2009. AB If P\&C Insurance $A S$ v. $U A B$,_trengimas" Supreme Court of Lithuania, Case No. Nr. 3K-3-516/2009.

Supreme Court of Lithuania. 2006. J. J., V. P. TÜB „Vikensta“ v. UAB ,Skala“. Supreme Court of Lithuania, Case No. 3K-3-135/2006.

Supreme Court of Lithuania. 2012. J. N. (J. N.) v. V. U. 2012. Supreme Court of Lithuania, Case No. $3 \mathrm{~K}-$ $3-420 / 2012$. 
Supreme Court of Lithuania. 2014b. DNSB „,Taurakalnio namai, Vilnius“ v. UAB „Santechnikos verslas". Supreme Court of Lithuania, Case No. 3K-3-20/2014.

Supreme Court of Lithuania. 2015. D. P. v. D. V. P. Supreme Court of Lithuania, Case No. 3K-3-634248/2015.

Supreme Court of Lithuania. 2010. R. P. company „Alna“ v. Foundation ,Tévo namai“, Kaunas City Municipal Administration. Supreme Court of Lithuania, Case No. 3K-3-380/2010.

Supreme Court of Lithuania. 2011. R. P. company „Alna" v. Foundation „Tèvo namai“, Kaunas City Municipal Administration. Kaunas Regional Court, Case No. 2A-237-260/2011.

Supreme Court of Lithuania. 2015. Sole proprietorship „Seno dvaro sodyba“ v. UAB „Rustonas“. Supreme Court of Lithuania, Case No. 3K-3-389969/2015.

Supreme Court of Lithuania. 2014a. UAB „Klaipedos hidrotechnika“ v. VI „, Klaipedos valstybinio jūru uosto direkcija". Supreme Court of Lithuania, Case No. 3K-3-3/2014.

Supreme Court of Lithuania. UAB „Nordlita“ v. UAB „Šiauliu šalna“. Supreme Court of Lithuania, Case No. 3K-3-473/2011.
Supreme Court of Lithuania. 2015. UAB „Sodo gidas“ v. L. S. 2015. Supreme Court of Lithuania, Case No. 3K-3-288-469/2015.

Supreme Court of Lithuania. 2012. UAB „, Stats kamps“ v. V. B. 2012. Supreme Court of Lithuania, Case No. 3K-3-504/2012.

Vennström, A.; Eriksson, P. E. 2010. Client perceived barriers to change of the construction process, Construction Innovation 10(2): 126-137. http://dx.doi.org/10.1108/14714171011037156

Wang, X.; Huang, J. 2006. The relationships between key stakeholders' project performance and project success: perceptions of Chinese construction supervising engineers, International Journal of Project Management 24(3): 185-276.

http://dx.doi.org/10.1016/j.ijproman.2005.11.006

Xia, B.; Chan, A. P. C. 2010. Key competences of design-build clients in China, Journal of Facilities Management 8(2): 114-129. http://dx.doi.org/10.1108/14725961011041161

Young-Jun, C. 2013. Direction of CM services defect liability in the CM contract, Journal of the Korea Institute of Building Construction 13(3): 209-221. http://dx.doi.org/10.5345/JKIBC.2013.13.3.209

Zaghloul, R.; Hartman, F. 2003. Construction contracts: the cost of mistrust, International Journal of Project Management 21(6): 419-424. http://dx.doi.org/10.1016/S0263-7863(02)00082-0 